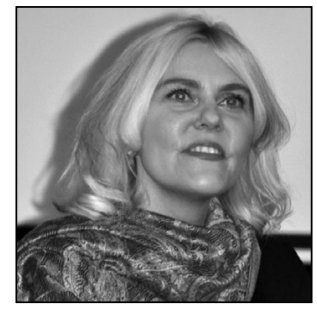

Julia Laffranque

Judge, European Court of Human Rights ${ }^{* 1}$

Visiting Professor, University of Tartu

\title{
A Look at the European Court of Human Rights Case Law on Moral Issues and Academic Freedom
}

\section{Introduction}

Moral issues are present in very many aspects of life and are involved in choices we make. Ethics is a subject that leaves no one of us indifferent and is constantly topical. This is true also in times of economic crises, in dealing with issues of migration and refugees and in coping with the threat of terrorism.

In almost all cases brought before it, the European Court of Human Rights (ECtHR, the Court) in Strasbourg faces more or less morally oriented issues. There are hardly any problems of life that have not been dealt with in the ECtHR case-law. More than 800 million people from the 47 member states of the Council of Europe can potentially turn to the Court in Strasbourg for help. As of 31 March 2017 there were 87,850 applications pending before the European Court of Human Rights. Most applications currently are from Turkey (in the aftermath of the coup d'état attempt, as well as of the curfew situation in south-eastern Turkey), Ukraine, Hungary, Romania and Russia, but quite many also arrive from Italy, Georgia, Azerbaijan, Poland and Armenia.

The present article will concentrate only on a few aspects of the case law of the European Court of Human Rights related to moral and ethical issues and will not go into depth on the more comprehensive, philosophical and social dimensions of this phenomenon. Firstly, the different dimensions of ethics at the European Court of Human Rights in general will be analysed. Secondly, some central topics related to moral issues in the case law of the European Court of Human Rights will be examined, and thirdly, more precisely, some of the judgements of the ECtHR that have dealt with academic freedom will be touched upon. Finally, a few concluding observations will be provided.

The article does not express any official opinions of the European Court of Human Rights and represents the author's personal views. 


\section{A few remarks about the different dimensions of ethics at the European Court of Human Rights}

Ethics in the European Court of Human Rights can be considered to have at least three dimensions:

a. On one hand, the first dimension of ethics in the Court is the common ethical grounds and European values on which the ECtHR decisions are often based;

b. On the other hand, the second dimension of the ethics consists of some differences in ethical grounds in cases where no European consensus on a given issue seems to exist. Ethics may then be used as a valid reason for leaving the decision-making within the margin of appreciation of the member states of the Council of Europe;

c. And the third dimension of ethics in the Court is the independence, impartiality and internal ethics of the ECtHR and its judges. The European Court of Human Rights itself needs to be human and ethical in order to deal with important human rights issues.

\subsection{Common ethical values in Europe}

As to the first dimension, the common ethical grounds, then, it is clear that certain ethical grounds are inherent to human rights. The Court has the authority to apply and interpret one of the most important human rights protection instruments in the world: the European Convention on Human Rights (Convention) of 1950, which came into force in 1953. The core of the Convention and its protocols is the right to life and prohibition of torture. Also important are the prohibition of slavery and forced labour, right to liberty and security, right to respect for private and family life and right to education and free elections, as well as procedural rights to a fair trial, effective remedy and no punishment without law. Furthermore, the Convention and its protocols guarantee several freedoms, such as freedom of thought, conscience and religion; freedom of expression; and freedom of assembly and association. These human rights documents (the Convention and its protocols) also protect property and prohibit discrimination as well as abolish the death penalty. Some of these rights are absolute, such as prohibition of torture and inhuman and degrading treatment. Others may be restricted, but these restrictions are only allowed if they are prescribed by law, necessary in democratic society and proportionate.

It is true that life has changed a lot since the 1950 s and the Court, as indeed the rest of the world, finds itself facing new issues of developments in society, bioethics and technologies (such as adoption of children by same-sex parents, artificial procreation, the right to euthanasia, freedom of speech on the Internet and many others). In several cases, domestic law lags behind reality and offers no answers to questions of this kind, so people come to the European Court of Human Rights in Strasbourg, where the judges will need to find answers. This is why the European Court of Human Rights has developed a doctrine of looking at the Convention as a living instrument and has interpreted the Convention in light of the modern society and its developments dynamically. ${ }^{{ }_{2}}$ For instance, the ECtHR has found that the right to private life also includes the protection of the environment. ${ }^{*}$ Along the same lines, the Court has created case law on protecting social rights that were not covered by the Convention.

And yet, according to the principle of subsidiarity ${ }^{*}$, it is first and foremost for the States of the Council of Europe themselves, including their domestic judiciaries, to guarantee the good protection of human rights. The Court only steps in if respect for human rights has not been achieved on national level.

\subsection{Differences in ethical values in Europe}

This brings us to the second dimension of ethics in the ECtHR. Here the question arises of whether the States may sometimes restrict the human rights in relying on their traditions, on ethical and/or moral grounds, or there is enough consensus in Europe on certain issues, such as, for example, same-sex marriages or

2 E.g., Tyrer v. UK, 25.04.1978, p. 31, Series A, no. 26, and Christine Goodwin v. UK [GC], no. 28957/95, p. 75, ECHR $2002-\mathrm{VI}$.

3 E.g., Guerra and Others v. Italy, nos. 116/1996/735/932, 19.2.1998.

4 Belgian Linguistic (merits), 23.07.1968, Series A, no. 6, p. 35, §10 in fine. 
surrogate mothers. Where there is no consensus, ethics and sensitive moral issues can be one of the reasons to leave this question to be decided on national level, without taking a final pan-European position, provided that the national situation is not manifestly breaching human rights. However, if consensus exists, then this common trend can be used by the European Court of Human Rights in order to push through certain all-European ethical moral standards without it necessarily creating them itself. This technique avoids the Court being criticised for not having respected the identity of these States, because the States anyhow have a certain consensus on certain ethical issues. ${ }^{*}{ }^{*}$ Nevertheless, it cannot avoid the fact that for some commentators the case-law of the Court may seem too conservative and for others again too liberal. It is important that the European Court of Human Rights avoid trying to please anybody; instead, it must remain faithful to the Convention standards.

\subsection{Ethical values in the Court}

This is why the third aspect of ethics in the Court is very vital: the ethics of decision-making within the European Court of Human Rights - the issues of conviction and emotions on one hand and responsibility and rationality on the other, finding the right balance between generalisation and deciding an individual case. One of the former judges of the ECtHR has said that the Court is like a jazz player; it improvises, but within the given limits. ${ }^{*}$ On 23 June 2008 the Plenary of the European Court of Human Rights adopted a resolution on judicial ethics, which stresses the importance of independence, impartiality, integrity, diligence and competence, as well as discretion of judges. ${ }^{* 7}$ The judges of the European Court of Human Rights are free to express their separate opinions if they do not agree with the majority judgement.

\section{Some central topics related to moral issues in the case-law of the European Court of Human Rights}

\subsection{Human dignity and ethics}

In order to develop the second part of this article, it is necessary to write a few words about human dignity, as this is closely connected with ethics.

Human dignity is, along with equality and liberty, a complicated, complex and vague concept, as pointed out by law professor Aharon Barak ${ }^{*}$, former president of the Supreme Court of Israel. The Convention does not mention expressis verbis human dignity, but it is included prominently in several later Council of Europe conventions, notably the Revised European Social Charter and the Convention on Human Rights and Biomedicine.

Interpretations of the former European Commission of Human Rights and the Court, particularly of Article 3 of the Convention, which prohibits torture and inhuman and degrading treatment and punishment, have drawn extensively on the concept of human dignity as a basis for the decisions. ${ }^{*}{ }^{*}$ The first references to human dignity appeared in the decision of the European Human Rights Commission in the East African Asians $v$. United Kingdom case in the 1970s, where the racial discrimination the applicants were subjected to constituted an infringement of their human dignity, which in the particular circumstances of the case (citizens of the United Kingdom from its colonies and UK passport-holders of Asian origin were not admitted to the UK) amounted to degrading treatment. ${ }^{*} 10$ The first reference by the European Court of Human Rights to human dignity was in 1978 in a judgement in the case Tyrer $v$. UK, ${ }^{*}{ }^{11}$ in which corporal

5 Jan Christian Urban, Freiheitsbeschränkungen aus Gründen von Ethik und Moral in Europa, Tectum: 2015, siehe auch: http://www.schleyer-stiftung.de/pdf/pdf_2012/leipzig_2012/Urban_Jan.pdf. S. (1.5.2017), S. 2.

6 Anatoly Kovler (Russia) during a judicial reflection meeting, 25.6.2012 (non-official records).

Available on the website of the Court: http://www.echr.coe.int/Documents/Resolution_Judicial_Ethics_ENG.pdf(1.5.2017).

8 Aharon Barak, Human dignity: constitutional value and constitutional right, Cambridge University Press, 2015. - DOI: https://doi.org/10.1017/CBO9781316106327.

9 Christopher McCrudden, Human Dignity and Judicial Interpretation of Human Rights, The European Journal of International Law (EIJL) (2008), Vol. 19, No. 4, pp. 655-724, on p. 683. - DOI: https://doi.org/10.1093/ejil/chn043.

$10 \quad$ East African Asians v. United Kingdom, 3 E.H.R.R. 76, 15.12.1973.

11 Cited above. 
punishment, administered as part of a judicial sentence, birching (i.e., caning) the then 15-year-old applicant, who had to take down his trousers and underpants, was held to be contrary to the Convention and an assault on a person's dignity and physical integrity. Since then, dignity has been drawn on in the context of the right to a fair hearing, the right not to be punished in the absence of a legal prohibition, the prohibition of torture and the right to private life. The European Court of Human Rights now regards human dignity as underpinning all of the rights protected by the Convention.

\subsection{Beginning of life and moral issues}

Most of the central topics related to moral issues that the Court has to tackle are connected with the beginning and end of life. The cases involving reproductive rights before the ECtHR have dealt with access to a lawful abortion, embryo donation and scientific research, home birth, medically assisted procreation, precautionary measures to protect a newborn baby's health, prenatal medical tests, sterilisation operations and forced sterilisations, surrogacy and an unborn child's right to life.

In a case called Vo $v$. France, owing to a mix-up with another patient, with the same surname, the applicant's amniotic sack was punctured, making a therapeutic abortion necessary. ${ }^{*}$ She maintained that the unintentional killing of her child should have been classified as manslaughter. The Court held in 2004 that there had been no violation of the right to life. It found that it was not currently desirable or possible to rule on whether an unborn child was a person under protection of the European human rights convention. And there was no need for a criminal-law remedy; remedies already existed in allowing the applicant to prove medical negligence and to seek compensation.

In A., B. and C. v. Ireland the Court found in 2010 that Ireland had failed to implement the constitutional right to a legal abortion. ${ }^{*} 13$ There had therefore been a violation of the right to respect for private and family life with regard to one applicant whose cancer was in remission, because she was unable to establish her right to a legal abortion either through the courts or via the medical services available in Ireland. The Court noted the uncertainty surrounding the process of establishing whether a woman's pregnancy posed a risk to her life and that the threat of criminal prosecution had a 'significant chilling effect' both on doctors and on the women concerned. ${ }^{*} 14$

Three years earlier, in Evans $v$. United Kingdom the ECtHR found that since the issue of when the right to life began came within the State's margin of appreciation, given the lack of European consensus, the embryos created by the applicant and her former partner did not have a right to life. ${ }^{*} 5$ The Court held that when the embryos were destroyed in accordance with national law because there was no longer consent of the applicant's former partner to use them, there had been no violation of the right to life.

However, in the case Dickson $v$. United Kingdom, later in the same year, 2007, the Court held that there had been a violation of the right to respect for private and family life as a fair balance had not been struck between the competing public and private interests. ${ }^{* 16}$ In this case, the applicant, who was a prisoner with a minimum 15-year sentence to serve for murder, was refused access in the UK to artificial insemination facilities to enable him to have a child with his wife, who had little chance of conceiving after his release. The European Court of Human Rights did not agree with UK authorities.

On the other hand, in S.H. and Others v. Austria, in 2011 the Court concluded that there had been no violation of the right to respect for private and family life in a case that concerned two Austrian couples wishing to conceive a child through IVF and ovum donation. ${ }^{* 17}$ The Court noted that, although there was a clear trend across Europe in favour of allowing gamete donation for in vitro fertilisation, the emerging consensus was still under development and was not based on settled legal principles. Austrian legislators had tried, among other things, to avoid the possibility that two women could claim to be the biological mother of the same child. They had approached carefully a controversial issue involving complex ethical questions. Besides, Austria had not banned individuals from going overseas for infertility treatment unavailable in Austria.

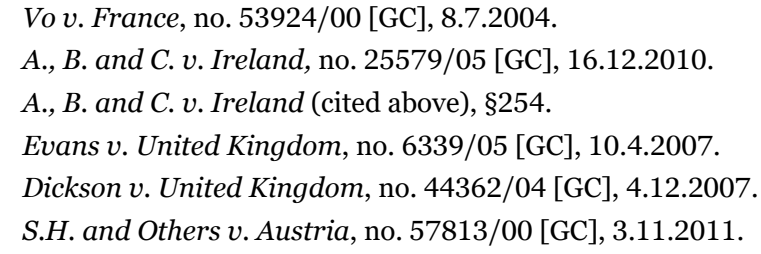


More recently, in the cases Mennesson and Others $v$. France and Labassee v. France, in 2014, which involved the refusal to grant legal recognition in France to parent-child relationships that had been legally established in the United States between children born as a result of surrogacy treatment and the couples who had had the treatment, the Court held that there had been no violation of the parents' right to respect for their family life, ${ }^{*}{ }^{*}$ but that there had been a violation of the children's right to respect for their private life.

However, in Paradiso and Campanelli $v$. Italy, the Court, itself admitting that it dealt with an ethical issue, held, by eleven votes to six, that there had been no violation of Article 8 (on the right to respect for private and family life) of the European Convention on Human Rights. ${ }^{*} 9$ The case pertained to the placement in social-service care of a nine-month-old child who had been born in Russia under a gestational surrogacy contract, entered into with a Russian woman by an Italian couple who had no biological relationship with the child. The Court concentrated on surrogacy instead of the proportionality of the measure, which consisted of taking the baby away from the couple and giving the child to others for adoption. ${ }^{* 20}$ The Court observed that the facts of the case touch on ethically sensitive issues - adoption, the taking of a child into care, medically assisted reproduction and surrogate motherhood - in connection with which Member States enjoy a wide margin of appreciation. ${ }^{* 1}$

Another Italian case, Parrillo $v$. Italy involved a ban under Italian law that prevented the applicant from donating to scientific research embryos obtained from an in vitro fertilisation that were not destined for a pregnancy. ${ }^{{ }_{22} 2}$ The Court, which was called upon for the first time to rule on this issue, held in August 2015 that the right to respect for private and family life set forth in the Convention was applicable in this case under its 'private life' aspect, as the embryos in question contained the applicant's genetic material and accordingly represented a constituent part of her identity. However, later, in Paradiso and Campanelli, the Court concluded that Italy was also to be given considerable room for manoeuvring (a 'wide margin of appreciation') in the field of embryo donations on this sensitive question, as confirmed by the lack of a European consensus and the international texts on this subject.

It is interesting that in another recent case, Dubská and Krejzová $v$. The Czech Republic, which involved home births and a legal ban on midwifes assisting in home delivery, the Court has, on the contrary, not found the issue at stake to be of a particular moral nature. ${ }^{*} 3$ The Court stated the following:

While the question of home birth does not as such raise acutely sensitive moral and ethical issues (see, by contrast, $A, B$ and $C v$. Ireland, cited above), it can be said to touch upon an important public interest in the area of public health. Moreover, the responsibility of the State in this field necessarily implies a broader boundary for the State's power to lay down rules for the functioning of the health-care system, incorporating both State and private health-care institutions. In this context the Court notes that the present case involves a complex matter of health-care policy requiring an assessment by the national authorities of expert and scientific data concerning the risks of hospital and home births. In addition, general social and economic policy considerations come into play, including the allocation of financial means, since budgetary resources may need to be shifted from the general system of maternity hospitals to the provision of a framework for home births. ${ }^{*} 4$

\subsection{End of life and moral issues}

As far as the end of life is concerned, in one of the first judgements of the Court on this subject, Pretty $v$. United Kingdom, the Court in 2002 held that there had been no violation of the right to life, finding that the right to life could not, without a distortion of language, be interpreted as conferring the diametrically opposite right, namely a right to die. ${ }^{*} 25$

18 Mennesson and Others $v$. France, no. 65192/11, 26.6.2014, and Labassee v. France, no. 65941/11, 26.6.2014.

19 Paradiso and Campanelli v. Italy, no. 25358/12 [GC], 24.1.2017; see e.g., §§ 182, 184, 194, 201, 203.

20 See also the joint dissenting opinion of judges Lazarova Trajkovska, Bianku, Laffranque, Lemmens and Grozev regarding the same judgement.

$21 \quad$ Paradiso and Campanelli $v$. Italy (cited above), §194.

22 Parrillo $v$. Italy, no. 46470/11 [GC], 27.8.2015.

23 Dubská and Krejzová v. The Czech Republic, nos. 28859/11 and 28473/12 [GC], 15.11.2016.

24 Dubská and Krejzová $v$. The Czech Republic (cited above), §182. See also, critical of the majority judgement, the dissenting opinion of judges Sajo, Karakas, Nicolaou, Laffranque and Keller.

25 Pretty $v$. United Kingdom, no. 2346/02, 29.4.2002. 
In this case, the applicant was dying of motor neurone disease, a degenerative disease affecting the muscles for which there is no cure. Given that the final stages of the disease are distressing and undignified, she wished to be able to control how and when she died. Because of her disease, the applicant could not commit suicide alone and wanted her husband to help her. But, although it was not a crime in English law to commit suicide, assisting a suicide was.

In subsequent cases, the Court has noted that the Member States of the Council of Europe were far from having reached a consensus with regard to the right of an individual to choose how and when to end his life. ${ }^{*} 26$

However, in 2012 the Court found in Koch v. Germany that Germany had violated a procedural aspect of the right to private and family life by refusal of its courts to examine the merits of the complaint of an applicant who wished to help his wife, who suffered a serious disease, to obtain a lethal dose of a drug in order to commit suicide at home in Germany. ${ }^{*} 2$

In a recent judgement, in Lambert and Others $v$. France in June 2015, the Court held that there would not be a violation of the right to life in the event of implementation of the French Conseil d'État judgement that confirmed the lawfulness of the decision of a panel of medical doctors to discontinue the artificial nutrition and hydration of Vincent Lambert. ${ }^{* 28}$ Vincent Lambert had sustained a head injury in a road-traffic accident in 2008 and in a result of that became tetraplegic. The Court once more observed that there was no consensus among Member States in favour of permitting the withdrawal of life-sustaining treatment. In that sphere the States must be afforded a margin of appreciation. The Court was, further, keenly aware of the importance of the issues raised in the case, which pertained to extremely complex medical, legal and ethical matters. In the circumstances of the case, the Court reiterated that it was primarily for the domestic authorities to verify whether the decision to withdraw treatment was compatible with the domestic legislation and the Convention, and to establish the patient's wishes. In said case, an in-depth examination of all aspects had been carefully conducted in France by the highest-ranking medical and ethical bodies.

As in many cases of this kind, the case was heard by the Grand Chamber and the Court was not unanimous, with dissenting opinions voiced.

In its decision in the case Gard and Others $v$. the United Kingdom ${ }^{* 29}$, the European Court of Human Rights on 27.6.2017, by a majority, endorsed in substance also the approach of the domestic courts and declared the application inadmissible by a final decision. Consequently, the Court also lifted the interim measure it had granted previously under Rule 39 of its Rules of Court. The case concerned Charlie Gard, a baby suffering from a rare and fatal genetic disease. In February 2017, the treating hospital sought a declaration from the domestic courts as to whether it would be lawful to withdraw artificial ventilation and provide Charlie with palliative care. Charlie's parents also asked the courts to consider whether it would be in the best interests of their son for him to undergo experimental treatment in the USA. The domestic courts in the United Kingdom concluded that it would be lawful for the hospital to withdraw life-sustaining treatment because it was likely that Charlie would suffer significant harm if his present suffering were prolonged without any realistic prospect of improvement and that the experimental therapy would be of no effective benefit. In the proceedings before the ECtHR, Charlie's parents argued - on their own behalf and that of their son - under Article 2 (on the right to life) that the hospital had blocked access to life-sustaining treatment (in the USA) for Charlie and under Article 5 (on the right to liberty and security) that, in consequence, he had been unlawfully deprived of his liberty. They further alleged under articles 6 (on the right to a fair trial) and 8 (on the right to respect for private and family life) that the domestic court decisions amounted to unfair and disproportionate interference with their parental rights. The Court bore in mind the considerable room for manoeuvring ('wide margin of appreciation') left to the authorities in the sphere related to access to experimental medication for the terminally ill and in cases raising sensitive moral and ethical issues, reiterating that it was not for the Court to substitute itself for the competent domestic authorities. From this perspective, the Court gave weight to the fact that a domestic legal framework - compatible with the Convention - was available for governing both access to experimental medication and withdrawal of life-sustaining treatment. Furthermore, the domestic court decisions had been meticulously argued, thorough and reviewed at three levels of jurisdiction with clear and extensive reasoning giving relevant and

26 E.g., Haas v. Switzerland, no. 31322/07, 20.1.2011.

27 Koch v. Germany, no. 497/09, 19.7.2012.

28 Lambert and Others $v$. France, no. 46043/14 [GC], 5.6.2015.

29 Gard and Others $v$. the United Kingdom, no. 39793/17, 27.6.2017. 
sufficient support for the conclusions; the domestic courts had direct contact with all those concerned; it was appropriate for the hospital to approach the courts in the UK in the event of doubts as to the best decision to take; and, lastly, the domestic courts had concluded, on the basis of extensive, high-quality expert evidence, that it was most likely Charlie was being exposed to continued pain, suffering and distress and that undergoing experimental treatment with no prospects of success would offer no benefit, and continue to cause him significant harm.

In Paposhvili v. Belgium, the Court did, however, reach a Grand Chamber judgement unanimously ${ }^{*} 30$, in a case involving an order for Paposhvili's deportation to Georgia, issued together with a ban on re-entering Belgium. Unfortunately, the applicant died before the end of proceedings in the ECtHR. Nevertheless, the Court examined the case and held, unanimously, that there would have been a violation of Article 3 (prohibition of inhuman or degrading treatment) of the European Convention on Human Rights if Paposhvili had been removed to Georgia without the Belgian authorities having assessed the risk faced by him in light of the information on his state of health and the existence of appropriate treatment in Georgia, and also a violation of Article 8 (right to respect for private and family life) if Paposhvili had been removed to Georgia without the Belgian authorities having assessed the impact of removal on the applicant's right to respect for his family life in view of his state of health.

These examples are just a drop of water in the sea of ethical problems examined by the Court in Strasbourg.

\subsection{Other topics related to moral issues in the European Court of Human Rights case-law}

The following topics can be mentioned as examples pointing to areas in which ethics and moral issues play an important role in front of the ECtHR:

Firstly, of course, the most serious human rights violations in general create moral problems: involvement of state authorities in killing and torturing people, tolerating torture and inhuman treatment, human trafficking, even slavery - problems that regrettably still exist in many European countries.

Then, another context for moral issues is the arbitrary deprivation of liberty in its own right, which can be combined with so many other factors, such as the victims being people who have participated in peaceful demonstrations or journalists who have been reporting on elections.

Next are the social, moral, family-rights and health issues, in which matters of poverty and human dignity are of importance. Can a pensioner in Russia who struggles to make ends meet with his/her retirement income apply to the Court for reason of suffering inhuman and degrading treatment? The Court has said yes but has not yet found a violation. ${ }^{*} 1$

As for family matters, parental rights, the best interests of a child and children's rights, cases of child abduction are to be emphasised. Must the Latvian courts examine a psychological report about a child whose mother has brought her child back to her mother's land (Latvia) before sending the child back to her father in Australia, where the child was forbidden to speak Latvian to her mother? The Court has answered yes. ${ }^{*}{ }^{32}$

As far as the recognition of homosexual partnerships is concerned, this question was raised: Can Greece allow registered partnership for heterosexual couples but forbid it for homosexual couples? The Court has said no - homosexuals enjoy the same right to private life and family as others ${ }^{*} 33$ - but the Court has not yet made a pronouncement as far as same-sex marriages are concerned, finding that there is no European consensus on the matter. Discrimination based on HIV-positive status has also caused ethical questions: the Court has condemned countries where employers have discriminated against employees because of their HIV infection, such as Russia and Greece, which refused a residence permit solely on account of the applicant's HIV infection. ${ }^{*} 34$

Let us consider two examples involving private life and ethical choices wherein the Court did not see a problem: on 8 October 2015, the European Court of Human Rights in the case Macalin Moxamed Sed

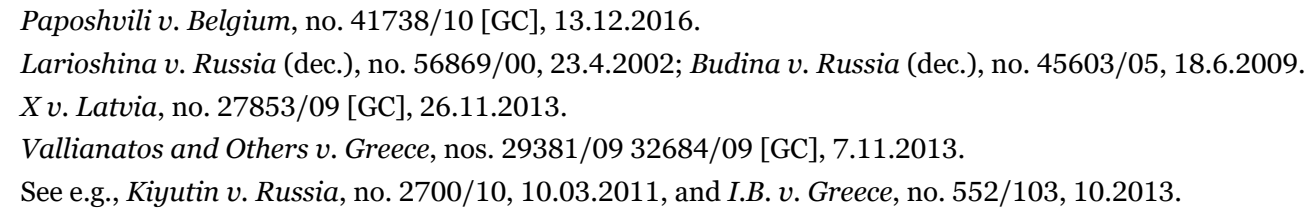


Dahir $v$. Switzerland unanimously declared the application inadmissible. ${ }^{*} 35$ The case involved a request by the applicant, a Somali and Swiss national, to change her surname on the grounds that the Swiss pronunciation of the name produced words with an offensive meaning in her mother tongue, Somali - namely, meanings such as 'rotten skin' and 'toilets'. The applicant had sought the possibility of using different spellings of her name but had been denied this in Switzerland. The European Court of Human Rights found, in assessing the possible breach of the applicant's private-life rights, the fact that the language in which offensive meaning was produced was Somali and not one of the national languages of the country where she lived, Switzerland, to be key. The applicant was therefore not comparable to persons whose names gain a ridiculous or humiliating meaning in a more common language such as the national languages of Switzerland.

In 2009 the Court dismissed an application of a family who argued that introducing an obligatory course in ethics in Berlin violated their freedom of religion. The Court confirmed that the purpose of the ethics course was independent from the cultural, ethical, religious or ideological background of the pupils; it dealt with general ethical issues; and it did not prevent the family from educating their children according to their convictions. ${ }^{*} 6$

Further issues with moral aspects are related to religion, such as those of Crucifixes and headscarves in public schools or prohibition to wear a burka in public places. The Court has allowed Crucifix display in Italian public schools on ethical-religious-art-historical grounds. ${ }^{*}{ }^{37}$ On the other hand, the Court has emphasised that applying the principle of 'living together' was a legitimate aim for the French law forbidding wearing a burka in public places in France, particularly as the State had a wide margin of appreciation as regards this general policy question on which there were significant differences of opinion. ${ }^{*} 8$

Another set of examples is that related to the controversial rights of prisoners and prison conditions as well as the fight against and prevention of terrorism. The Court has been faced with applications from prisoners who suffer under degrading prison conditions and has ruled many times to urge Member States to improve their situation, calling, for example, on the UK to abandon its blanket ban on prisoners voting. ${ }^{*} 39$ The Court has also heard applicants who have been victims of terrorist attacks and helped them on their way to finding justice and proper investigation on national level. ${ }^{*} 40$ On the other hand, the Court has also ruled on the rights of terrorists or terrorism suspects, as in rendition cases. ${ }^{* 41}$ The delicate issue of terrorism prevention involves what measures to take and when. For example, what about general wire-tapping in connection with terrorism prevention?

A further very sensitive topic concerns refugees and migrants. The Court has pointed out the prohibition of inhuman and degrading treatment of asylum-seekers and warned States to examine individual applications and circumstances case by case. ${ }^{*} 42$

Then there are conflicts of a political nature and armed conflicts that find their way to the Court, such as inter-state applications, between, for example, Cyprus and Turkey, Georgia and Russia or Ukraine and Russia.

Another bundle of problems is found in the economic power and violation of human rights by big private companies and other enterprises; often these issues are connected with ethics and also, for example, with protection of the environment (pollution by big companies causing health problems to their employees and people who live in the neighbourhood). States can also have obligations to avoid violation of the Convention by private persons and enterprises. Sometimes the property rights involve ethical dilemmas, especially in the framework of privatisation or nationalisation and eviction.

Last but not least is freedom of expression: the Court has considered freedom of expression a cornerstone of democracy, and it has considered journalism and media a 'public watchdog' ${ }^{*} 43$ and has protected

\footnotetext{
Macalin Moxamed Sed Dahir v. Switzerland, (dec.) no. 12209/10, 15.9.2015.

Appel-Irrgang and Others v. Germany (dec.), no. 45216/07, 6.10.2009.

Lautsi and Others v. Italy, no. 30814/06 [GC], 18.3.2011.

SAS v. France, no. 43835/11 [GC], 1.7.2014.

Hirst $v$. United Kingdom (2), no. 74025/01 [GC], 6.10.2005.

E.g., Tagayeva and Others $v$. Russia, nos. 26562/07, 14755/08, 49339/08, 26562/07, 14755/08 and 49339/08, 13.4.2017.

El Masri v. FYRM, no. 39630/09 [GC], 13.12.2012.

42 See, e.g., M.S.S. v. Belgium and Greece [GC], no. 30696/09, 20.1.2011, and Tarakhel v. Switzerland, no. 29217/12 [GC], 4.11.2014.

43 See Bladet Tromsø and Stensaas v. Norway, no. 21980/93 [GC], §§ 59 and 62, ECHR 1999-III, and Pedersen and Baadsgaard v. Denmark, no. 49017/99 [GC], §71, ECHR 2004-XI.
} 
also the imparting of ideas that may be shocking. Restrictions of freedom of expression must always be interpreted very strictly and are only allowed if they are necessary, for instance, for the protection of health or morals. Yet the media plays an increasingly important role not only in enlightenment and supporting freedom of thought but also in sometimes violating privacy rights. It goes without saying that ethics in journalism is extremely important. Furthermore, new forms of media on the Internet and in the digital world, such as social media (Facebook, blogging, etc.) have become increasingly widespread. The Court was confronted with this kind of issue for the first time in the case Delfiv. Estonia, where the Court found in June 2015 that there had been no violation of applicant company Delfi's right to impart information although it had been found liable in domestic courts for displaying anonymous user comments on its website with the nature of hate speech and speech inciting violence against a certain individual. ${ }^{*} 44$ The European Court of Human Rights agreed with the Estonian courts.

One can also see ethical issues related to procedural and trial rights: ethics of lawyers and prosecutors, investigators, experts and judges in order to guarantee a fair trial. Finally, procedure and judgements that have been based on ethical values have no meaning if they are not subject to implementation. This is why the Court has repeatedly held that a fair trial does not end with a judgement but also entails the execution of judgements, because rights must be not only theoretical - they must be not illusory but real and enforceable. ${ }^{*} 45$

\section{Selected judgements of the European Court of Human Rights related to freedom of research and the responsibility of researchers and universities}

\subsection{The essence of academic freedom and morals}

Academic freedom and autonomy to exercise it is essential for development of creativity, critique and scientific capacity. It is essential for democratic society in general; it is one of the indicators of how democratic a society is. As three judges of the European Court of Human Rights have expressed in a joint concurring opinion,

[t]here is no Chinese wall between science and a democratic society. On the contrary, there can be no democratic society without free science and free scholars. This interrelationship is particularly strong in the context of social sciences and law, where scholarly discourse informs public discourse on public matters. ${ }^{*} 6$

International human rights law protects academic freedom generally as independently and interdependently derived from freedom of expression and the right to education. ${ }^{*} 47$

Over time, the European Court of Human Rights has been confronted with issues touching upon cultural rights: the right to artistic expression, to cultural and linguistic identity, to seek historical truth. In the case Leyla Sahin $v$. Turkey, in 2005, the Court confirmed that the right to education applies also to higher and university education. ${ }^{*} 48$

Of course, the Court has underlined the importance of academic freedom. According to it, academic freedom 'comprises the academics' freedom to express freely their opinion about the institution or system in which they work and freedom to distribute knowledge and truth without restriction'. ${ }^{49}$ Referring

44 Delfi AS v. Estonia, no. 64569/09 [GC], 16.6.2015.

45 See, e.g., Case Relating to Certain Aspects of the Laws on the Use of Languages in Education in Belgium, ECtHR nos. 1474/62 et al., 13.7.1968, §§ 3 and 4; Marckx v. Belgium, ECtHR, no. 6833/74, 13.06.1979, §31.

46 Joint concurring opinion of judges Sajo, Vucinic and Kuris, judgement in Mustafa Erdogan and Others v. Tukrey, no. 346/04 39779/04, 27.5.2014.

47 Robert Quinn, Jesse Levine, Intellectual-HRDs and claims for academic freedom under human rights law, The International Journal of Human Rights, 2014, Vol. 18, Nos. 7-8, pp. 898-920, on p. 913. - DOI: http://dx.doi.org/10.1080/13642987. 2014.976203.

48 Leyla Sahin v. Turkey, no. 44774/98 [GC], 10.11.2005.

49 Sorguç v. Turkey, no. 17089/03, 23.06.2009, §35. 
to Recommendation 1762 (2006) of the Parliamentary Assembly of the Council of Europe, on academic freedom and university autonomy, the Court has stated that academic freedom in research and in training should guarantee freedom of expression and of action, freedom to disseminate information and freedom to conduct research and distribute knowledge and truth without restriction. Academic freedom covers even controversial or unpopular views, in the areas of research, professional expertise and scholarly competence. The Court must submit to careful scrutiny any restrictions on the freedom of academics to carry out research and to publish their findings.

\subsection{Classical cases at the European Court of Human Rights involving academic freedom}

Classical cases of academic freedom before the Court have involved the right to impart freely ideas on university life (recruitment, elections and management) during university meetings and conferences. There have also been cases about academic views and critique related to certain subject matter in academic form in specialised journals related to the field of research of scholars who express their views, but even beyond that academic freedom may not be limited to debates in scholarly journals, debates in academic settings and teaching only but covers also academics' addresses to the general public - of which, by the way, academics themselves are also part. Sometimes the violations of academic freedom go beyond violations of freedom of expression and can consist, for example, in confiscating certain scientific works or forbidding them from being published, or even in some cases ordering restrictions of travel and hindering the free movement of higher-education personnel as with forbidding foreign lecturers to enter the country for reason of views expressed previously. Furthermore, violations can occur in the framework of recruitment - for instance, in the form of refusal to consider job applications of lecturers because of their views and statements. In extreme cases, academic-freedom violations can be manifested also in arbitrary detention of scholars for views they have expressed. The European Court of Human Rights has disapproved of all these kinds of violations.

An issue related to academic freedom is the question of how research results will be used and to whom the information about these results can be passed; it is related to privacy rights, data protection and copyright, as well as ownership issues.

There can also be other aspects of university life that have a link to academic freedom, such as legislation imposing entrance examinations and numerus clausus in certain disciplines.

In 2009 the Court found a violation of academic freedom in the case Sorguç $v$. Turkey, where a university lecturer was ordered to pay damages for having, at a scientific conference, distributed a document criticising the procedures for recruiting and promoting assistant lecturers. ${ }^{*} 50$

In a more recent judgement, of October 2015 in the case Kharlamov $v$. Russia, the Court found that a university's right to reputation under the European Convention on Human Rights is more limited than that of an individual. ${ }^{*}{ }^{1}$ The case centred on a civil action on defamation brought against a university professor in physics, by his employer, Orel State Technical University, after the professor expressed at a university-wide conference the view that the university's governing body could not be considered legitimate, on account of shortcomings in the election procedure. The court decided that the domestic courts, in their decisions against the professor, had failed to take into account the specific features of academic relations and failed to strike a fair balance between the need to protect the university's reputation and Kharlamov's freedom to express his opinion on the organisation of academic life.

In another rather recent judgement, from 2014, in the case Mustafa Erdogan and Others $v$. Turkey, the Court found a violation of academic freedom. ${ }^{*}{ }^{2}$ The case involved a complaint by a law professor, editor and publisher that they were ordered by the Turkish courts to pay damages to three judges of the Constitutional Court for insulting them in a law journal article that reported on a decision dissolving a political party. The Court stated that members of the judiciary acting in an official capacity should expect to be subject to wider limits of acceptable criticism than ordinary citizens. Both the context (fierce public debate on the Constitutional Court's rulings) in which the article had been written and the form (a quasi-academic

\footnotetext{
50 Cited above.

51 Kharlamov v. Russia, no. 27447/07, 8.10.2015.

52 Mustafa Erdogan and Others $v$. Turkey (cited above).
} 
journal, not a popular newspaper) used had not been given sufficient consideration by the national courts in the defamation proceedings against the applicants.

In a freedom of expression case, Hasan Yazıcı v. Turkey, ruled on in 2014, the Court was indirectly confronted with issues of plagiarism. ${ }^{*} 3$ In this case, the applicant, Hasan Yazıcı, had been ordered to pay damages for defamation of an influential academic whom he had accused of plagiarism in an article in a daily newspaper. Yazıcı, an academic himself and former head of the ethics committee of the Turkish Academy of Sciences, accused a prominent academic and former president of the Higher Education Council, Professor I.D., of plagiarising another professor's work to write one of his books. The subject matter of the article was the establishment of an ethics committee by the Higher Education Council in order to tackle plagiarism in academia, and was thus topical. The national courts ordered Yazici to pay the professor compensation, finding that the allegations of plagiarism were untrue and amounted to insult. The Court stated that it is not its task to rule on the issue of the veracity of the applicant's allegations of plagiarism. Rather, its examination of the issue is essentially from the standpoint of Convention conformity, the relevance and sufficiency of the reasons given by the domestic courts and the procedural guarantees applied.

\subsection{Other types of academic-freedom cases and procedural rights at the European Court of Human Rights}

The importance of academic freedom has also been stressed in relation to the seizure of a book that reproduced a doctoral thesis on the 'star' phenomenon. The domestic court had ordered the seizure on the grounds that it infringed the personality rights of a very well-known pop singer in Turkey. ${ }^{*} 54$ The ECtHR found a violation of the freedom of expression of the author of the book, because domestic courts failed to give any reasons for the seizure.

The Court has also weighed the freedom of expression over the right to private life and found no violation of the right to private life in the case Aksu v. Turkey in 2012. ${ }^{*} 55$ In this case, the applicant, Mustafa Aksu, a Turkish national of Roma origin, complained that passages in a government-funded academic book about Roma and definitions in two dictionaries were offensive and discriminatory, reflected anti-Roma sentiment and humiliated them by describing them as Gypsies and living from pick-pocketing. But the ECtHR held that in the particular circumstances of the case, the authorities had taken all the necessary steps to comply with their obligation to protect the applicant's effective right to respect for his private life as Roma but had also taken into account principles related to academic freedom.

The judgement in Cox $v$. Turkey, from 2010, addresses a new aspect of academic freedom of expression, that of a foreign university lecturer, and its consequences for leave to enter and remain in a Contracting State. The applicant, an American lecturer who had taught on several occasions in Turkish universities and had expressed opinions on Kurdish and Armenian questions, was banned from re-entering Turkey on the grounds that she would undermine 'national security'. The Court found a violation of freedom of expression. ${ }^{*} 56$

Freedom of academic expression protected by the European Convention on Human Rights also entails procedural safeguards for professors and lecturers. In the case of Lombardi Vallauri $v$. Italy ${ }^{* 57}$, the Council of the Law Faculty of the Catholic University of Milan refused to consider a job application by a lecturer who had taught philosophy of law there for more than twenty years on annual renewable contracts, on the grounds that the Congregation for Catholic Education had not given its approval and instead had simply noted that certain statements by the applicant were 'clearly at variance with Catholic doctrine'. The European Court of Human Rights observed that the Faculty Council had not informed the applicant, or made an assessment, of the extent to which the allegedly unorthodox opinions he was accused of holding were reflected in his teaching activities, or of how they might, in consequence, affect the university's interest in providing an education based on its own religious beliefs. Therefore, the Court concluded that the university's interest in providing an education based on Catholic doctrine could not extend so far as to undercut the very essence of the procedural safeguards.

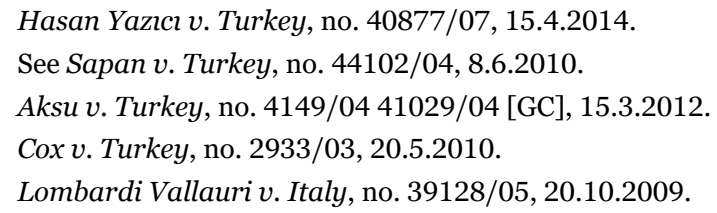


On the contrary, in the judgement in the case Fernández Martínez $v$. Spain, of $2014^{*}{ }^{*}$, the Court held by nine votes to eight that there had been no violation of the right to respect for private and family life of applicant Fernández Martínez. The case pertained to the non-renewal of the contract of a married priest and father of five who taught Catholic religion and ethics, after he had been granted dispensation from celibacy and following an event at which he had publicly displayed his active commitment to a movement opposing Church doctrine. In the ECtHR's view, it was not unreasonable for the Church to expect particular loyalty of religious-education teachers, since they could be regarded as its representatives. Any divergence between the ideas to be taught and the personal beliefs of a teacher could pose a problem of credibility when that teacher actively challenges those ideas.

In the case of Perinçek $v$. Switzerland, the European Court of Human Rights held, by a majority, that there had been a violation of the freedom of expression of applicant Perinçek, a doctor of laws and a Turkish politician who was chairman of the Turkish Workers' Party. ${ }^{*} 59$ The case centred on the criminal conviction of Perinçek for publicly expressing the view, at public gatherings in Switzerland, that the mass deportations and massacres suffered by the Armenians in the Ottoman Empire in 1915 and the following years had not amounted to genocide. The Court had to strike a balance between the right to freedom of expression of Perinçek and the right to respect for private life of the Armenian community - taking into account the specific circumstances of the case and the proportionality between the means used and the aim intended to be achieved. The Court concluded that it had not been necessary, in a democratic society, to subject Perinçek to a criminal penalty in order to protect the rights of the Armenian community at stake in this case.

\subsection{Use of research results and academic freedom}

As far as making research materials public is concerned, in a judgement in 2012, in the case Gillberg $v$. Sweden, ${ }^{*} 60$ the Court found that applicant Gillberg, an academic in Sweden, could not rely on his right to privacy and did not have a 'negative' right within the meaning of freedom of expression to refuse to make certain research material belonging to his public employer, Gothenburg University, available. The applicant was convicted in Sweden and given a suspended sentence and a fine for misuse of office in his capacity as a public official, for refusing to grant access to two individuals, under specified conditions, to research conducted by the University of Gothenburg. The ECtHR rejected the claim by Gillberg that he could invoke a right similar to that of journalists of having their sources protected and concluded that the refusal of Gillberg to grant access hindered the free exchange of opinions and ideas on the research in question.

As far as the legislation imposing entrance examination with numerus clausus for access to public- and private-sector university courses is concerned (for example, in medicine and dentistry), the European Court of Human Rights found no violation of the right to education in imposing numerus clausus in Italy, in the case Tarantino and Others $v$. Italy, in 2013. ${ }^{* 61}$

\section{Conclusions}

In a vast majority of cases, the European Court of Human Rights is confronted with ethical and moral issues. Some of them come down to the very core of human rights and human dignity. On some of these issues, sometimes minimum standards and consensus on European level exists; at other times, it is left for the States to approach ethical questions. The European Court of Human Rights looks at these issues with an open mind and takes into account the dynamics of the development of our society. At the same time, the Court respects, to a certain extent, traditions, history and cultural background as long as it does not result in arbitrary application and in disrespect of human rights. By carefully balancing different rights, as well as public and private interests, the Court sometimes pragmatically seeks out a middle ground. There does not necessarily need to be a 'European ethics', but there certainly exist certain common values and understandings.

\footnotetext{
Fernández Martínez v. Spain, no. 56030/07 [GC], 12.6.2014.

Perinçek v. Switzerland, no. 27510 [GC], 15.10.2015.

Gillberg v. Sweden, no. 41723/06 [GC], 3.4.2012.

Tarantino and Others $v$. Italy, no. 25851/09 29284/09 64090/09, 2.4.2013.
} 
Pope Francis underlined in his speech before the European institutions in 2014 the problem of global indifference ${ }^{*} 62$. One could also add hypocrisy. They both often prevent states from arriving at ethical solutions. Furthermore, abuse of human rights can turn good intentions into extremism. The European Court of Human Rights can hardly prevent new violations; it can point out systemic and structural problems and call for no further violations, and, while many examples have been provided in this paper, not nearly all cases find their way to the ECtHR. This is why an awareness of one's rights, involvement of NGOs and civil society and providing education and training also in ethics (starting with families and schools) is of vital importance. In 2009 the Court noted in the decision on an obligatory course in ethics in Berlin that the purpose of said course was to deal with general ethical issues and found it important.

The European Court of Human Rights looks beyond mere formalism and looks at these European values and justice because justice cannot be sacrificed for the sake of mere formalities, as long as a suitable balance between justice and legal certainty is preserved. The Court has in its case-law continuously stressed the importance of academic freedom and in most of the cases, the majority of which have been in respect of Turkey, ruled in favour of academic freedom of expression of individuals, whereas it has said that the right to reputation of a university is more limited than that of an individual. The Court, inspired by the general freedom of expression cases, has laid down certain criteria for examining this kind of case, such as where, in what context and with what content the views have been expressed. When considering the developments in research, the Court has been more modest and prudent. Here one must, of course, not forget also the importance of legislative decision-making on national level.

Anatole France has written: 'A good judge should have the spirit of a philosopher and a simple goodness. ${ }^{* 63}$

It is not easy to live up to the high expectations that the applicants have often set for the Court and to bear the Member States' careful and critical look at our case-law. It needs strong and solid legal, ethical and other legitimate bases for the Court to take up this huge responsibility, a responsibility that ideally should be shared with States. But it also takes a lot of courage to admit mistakes and change the case-law if really need be; after all, the European Court of Human Rights is the conscience of Europe.

62 Pope Francis: Address to European Parliament - full text, Vatican Radio, 25 November 2014, http://www.news.va/en/ news/pope-francis-address-to-european-parliament (1.5.2017).

63 Le bon juge devrait unir l'esprit philosophique à la simple bonté. Citation d'Anatole France; Opinions sociales - 1902. 